\title{
Postępowanie kwalifikacyjne wobec kandydatów do służby w formacjach mundurowych
}

\section{Wprowadzenie}

Funkcjonariusze tzw. służb mundurowych ${ }^{2}$ pełnią służbę w regulowanych prawem administracyjnym stosunkach służbowych. Powstają one na podstawie mianowania o przyjęciu do służby będącego decyzją administracyjną. Jej wydanie poprzedza postępowanie kwalifikacyjne, które ma na celu wyselekcjonowanie spośród wszystkich ubiegających się o nawiązanie stosunku służbowego osób, które w największym stopniu dają rękojmię należytego wypełniania obowiązków służbowych. Ustawodawca nie zdecydował się na wprowadzenie jednolitego dla wszystkich formacji mundurowych modelu postępowania kwalifikacyjnego, co jest uzasadnione specyfiką zadań realizowanych przez poszczególne formacje ${ }^{3}$. Niezależnie jednak od uzasadnionych różnic między postępowaniami kwalifikacyjnymi w poszczególnych formacjach mundurowych można wskazać zasadnicze podobieństwo, które polega na tym, że wszystkie wiążą się z prawem dostępu do służby publicznej ${ }^{4}$, ustanowionym w art. 60 Konstytucji RP z dnia 2 kwietnia 1997 r. ${ }^{5}$ Prawo to przysługuje obywatelom polskim korzystającym z pełni praw publicznych. Należy jednak pamiętać, że ustawodawca zwykły jest uprawniony do sformułowania dodatkowych warunków,

1 Dr Mariusz Wieczorek, Katedra Prawa Prywatnego i Gospodarczego, Wydział Nauk Ekonomicznych i Prawnych, Uniwersytet Technologiczno-Humanistyczny im. K. Pułaskiego w Radomiu.

$2 \mathrm{Na}$ potrzeby niniejszego artykułu przyjęto, że służby mundurowe obejmują następujące formacje: Agencję Bezpieczeństwa Wewnętrznego (ABW), Agencję Wywiadu (AW), Biuro Ochrony Rządu (BOR), Centralne Biuro Antykorupcyjne (CBA), Państwową Straż Pożarną (PSP), Policję, Służbę Więzienną (SW), Straż Graniczną (SG), Służbę Wywiadu Wojskowego (SWW) oraz Służbę Kontrwywiadu Wojskowego (SKW).

3 Różnice są przede wszystkim efektem pewnych odmienności w zakresie przesłanek nawiązania stosunku służbowego w danej formacji, co wpływa na ilościowy zakres czynności podejmowanych w toku postępowania.

4 Por. wyrok SN z dnia 9 czerwca 2010 r., III KRS 4/10, LEX nr 611831.

5 Dz. U. Nr 78, poz. 483 ze zm. 
uzależniając od ich spełnienia uzyskanie określonych stanowisk w służbie publicznej, z uwzględnieniem ich rodzaju oraz istoty ${ }^{6}$. Ponadto organy władzy publicznej muszą określić liczbę obsadzanych stanowisk stosownie do potrzeb państwa. W tym zakresie z reguły nie mają pełnej swobody, jako że limity zatrudnienia określane są $\mathrm{w}$ ustawie budżetowej, a niekiedy w sposób sztywny wyznaczane przepisami bezwzględnie obowiązującymi ${ }^{7}$.

Nie ulega jednak wątpliwości, że $\mathrm{z}$ art. 60 Konstytucji RP wynika obowiązek zapewnienie równości szans dla osób podejmujących starania o pełnienie funkcji w służbie publicznej. Z jednej strony przepis ten wymaga od ustawodawcy ustanowienia regulacji materialnoprawnych, określających przejrzyste kryteria selekcji kandydatów i obsadzania poszczególnych stanowisk w służbie publicznej, zaś z drugiej strony nakazuje stworzenie odpowiednich gwarancji proceduralnych, zapewniających możliwość weryfikacji decyzji w sprawie naboru do służby. Brak odpowiednich procedur kontrolnych i odwoławczych może stanowić istotną przeszkodę w stosowaniu przyjętych reguł i skutkować naruszeniem konstytucyjnego wymogu traktowania starających się o dostęp do służby na jednakowych zasadach.

Celem opracowania jest rozstrzygnięcie wątpliwości co do charakteru prawnego postępowań kwalifikacyjnych, charakteru aktu kończącego te postępowania oraz dokonanie oceny przepisów regulujących postępowania kwalifikacyjne w aspekcie prawa dostępu do służby publicznej i formalnych gwarancji tego prawa.

\section{Postępowanie kwalifikacyjne a prawo dostępu do służby publicznej}

Postępowanie kwalifikacyjne wobec kandydatów do pełnienia służby $\mathrm{w}$ formacjach mundurowych ma na celu ustalenie, czy kandydat ubiegający się o przyjęcie do służby w formacji mundurowej spełnia określone ustawowo warunki do pełnienia służby. Przed przejściem do szczegółowych rozważań tej kwestii warto wspomnieć, że nawiązanie każdego stosunku zatrudnienia, zarówno regulowanego prawem pracy, prawem cywilnym, jak i administracyjnym, poprzedzają czynności mające na celu zweryfikowanie przydatności kandydata do wykonywania określonej pracy. O ile jednak przy zatrudnianiu osób w służbie publicznej ustawodawca nie tylko określa wymogi rekrutacyjne, ale i mniej lub bardziej szczegółowo reguły prowadzenia tego postępowania, to w sektorze prywatnym decydujące

6 Należą do nich w szczególności niekaralność, odpowiednia postawa etyczna, gotowość do podania się szczególnej dyscyplinie służbowej, zdolność psychofizyczna do pełnienia służby.

7 Przykładem może być określenie sposoby naliczeń w tryb naliczania etatów dla komend wojewódzkich i powiatowych (miejskich) określony w rozporządzeniu Ministra Spraw Wewnętrznych i Administracji z dnia 26 lipca 2006 r. w sprawie ramowej organizacji komendy wojewódzkiej i powiatowej (miejskiej) Państwowej Straży Pożarnej, Dz. U. Nr 143, poz. 1037 ze zm. 
znaczenie ma wola zatrudniającego. Pracodawca, niepodlegający szczególnym regulacjom prawa pracy $^{8}$, rekrutując pracowników, musi uwzględnić relatywnie niewiele wymogów przewidzianych przepisami powszechnego prawa pracy. Musi mieć na uwadze ograniczenia swobody w zatrudnianiu wynikające z minimalnego wieku osób poszukujących pracy, wymogi w zakresie zdolności do pracy ${ }^{9}$ oraz przestrzegać zakazu dyskryminacji, które to okoliczności są łatwe do stwierdzenia i nie wymagają stosowania szczególnej procedury ${ }^{10}$. Różnica co do zakresu unormowania postępowania poprzedzającego zatrudnienie w sektorze publicznym i prywatnym jest konsekwencją tego, że zatrudnianie w sektorze prywatnym służy realizacji przede wszystkim interesu prywatnego, a odpowiednia selekcja kandydatów w służbie publicznej, a zwłaszcza chętnych do podjęcia służby w formacjach mundurowych, zapewnia w pierwszym rzędzie ochronę interesu publicznego polegającego $\mathrm{w}$ tym przypadku na pełnieniu służby przez osoby, które spełniają określone $\mathrm{w}$ prawie materialnym przesłanki w możliwie najwyższym stopniu. Stąd też to właśnie w związku z nawiązywaniem stosunku służbowego konieczne jest takie unormowanie procesu kwalifikacyjnego, by z jednej strony został osiągnięty podstawowy cel postępowania, czyli obsadzenie wakującego stanowiska, a z drugiej strony została zagwarantowana realizacja praw obywatelskich. Wchodzącym w grę prawem jest prawo obywatela dostępu do służby publicznej, zagwarantowane w art. 60 Konstytucji RP. Zgodnie z utrwalonym w orzecznictwie poglądem przepis ten gwarantuje każdemu obywatelowi korzystającemu z pełni praw publicznych prawo ubiegania się o przyjęcie do służby publicznej, nie gwarantuje natomiast przyjęcia do tej służby ${ }^{11}$. Z art. 60 Konstytucji wypływa obowiązek zapewnienia równości szans dla osób podejmujących starania o zatrudnienie w służby publicznej i nakaz stworzenia odpowiednich gwarancji proceduralnych, zapewniających weryfikowalność decyzji w sprawie naboru do służby. Brak odpowiednich procedur kontrolnych i odwoławczych stanowić może istotną przeszkodę w stosowaniu przyjętych reguł, a tym samym naruszać będzie konstytucyjny wymóg traktowania starających się o dostęp do służby na jednakowych zasadach ${ }^{12}$.

8 Chodzi o wymogi wynikające przede wszystkim $\mathrm{z}$ tak zwanego urzędniczego prawa pracy.

9 Nie można przy tym pominąć wymogów epidemiologiczno-sanitarnych związanych z wykonywaniem niektórych prac.

$10 \mathrm{~W}$ praktyce, zwłaszcza przy obsadzaniu stanowisk kierowniczych, są jednak stosowane wielostopniowe procedury, mające charakter konkursu, zasady którego określa podmiot zatrudniający.

11 Wyrok SN z dnia 8 czerwca 2011 r., III KRS 6/11, LEX nr 1095942; wyrok SN z dnia 9 czerwca 2010 r., III KRS 4/10.

12 Wyrok TK z dnia 9 czerwca 2010 r. Zob. też wyroki TK: z dnia 9 czerwca 1998 r., K 28/97, „Orzecznictwo Trybunału Konstytucyjnego” 1998, nr 4, poz. 50; wyrok TK z dnia 8 kwietnia 2002 r., SK 18/01, „Orzecznictwo Trybunału Konstytucyjnego", seria A 2002, nr 2, poz. 16. 
Warunkiem sine qua non realizacji tego prawa jest podanie do powszechnej wiadomości informacji o wolnych stanowiskach w służbie publicznej. O realizacji prawa do dostępu do służby nie można mówić, jeśli wiedza o wakatach będzie ograniczona jedynie do pewnego kręgu osób. Zwraca uwagę, że kwestie związane z określeniem specyfiki postępowania kwalifikacyjnego oraz sposobem upubliczniania informacji o jego prowadzeniu unormowane są w aktach prawnych różnej o różnej randze, zarówno w ustawach, jak i rozporządzeniach. Różnice występują również, gdy idzie o określenie istoty postępowania kwalifikacyjnego oraz techniczną stronę upowszechnienia informacji o naborze. Jak wynika $\mathrm{z}$ analizy przepisów regulujących postępowania kwalifikacyjne w służbach mundurowych expressis verbis, prawny obowiązek informowania o naborze został przewidziany wyłącznie w przepisach regulujących organizację i funkcjonowanie Policji, Państwowej Straży Pożarnej oraz Służby Więziennej. Gdy idzie o formę upublicznienia informacji o naborze, odpowiednie przepisy stanowią, że stosowne informacje umieszcza się na właściwej stronie internetowej, w Biuletynie Informacji Publicznej czy we właściwych terytorialnie powiatowych i wojewódzkich urzędach $\operatorname{pracy}^{13}$. Podobieństwo przedmiotu regulacji nie uzasadnia takiego zróżnicowania. De lege ferenda w tych wypadkach, w których przepisy nakazują upublicznienie informacji $\mathrm{o}$ wakatach $\mathrm{w}$ formacji, uzasadnione jest jednolite unormowanie $\mathrm{w}$ zakresie upublicznienia informacji o prowadzonym naborze. Swoistym minimum powinien być obowiązek podania tych informacji w Biuletynie Informacji Publicznej oraz przekazania informacji do urzędów pracy.

W tym miejscu zasadne staje się postawienie pytania, czy informacje o wolnych stanowiskach i prowadzonym naborze należy upubliczniać $\mathrm{w}$ jednakowym zakresie i w odniesieniu do wszystkich formacji. Watpliwość ta jest szczególnie aktualna w odniesieniu do służb specjalnych, to jest ABW, AW, CBA, SKW oraz SWW. Istota ich działania, będąca następstwem wykonywanych przez nie zadań, jest tego rodzaju, że może uzasadnić odmienne niż wyżej przedstawione rozwiązanie kwestii informacji o naborze do tych formacji. Z uwagi na brak uregulowań prawnych w tym zakresie warto zwrócić uwagę, że formacje te na swoich stronach internetowych zamieszczają informacje o wymaganiach kwalifikacyjnych wobec kandy-

13 Por. $\$ 5$ rozporządzenia Ministra Spraw Wewnętrznych z dnia 18 kwietnia 2012 r. w sprawie postępowania kwalifikacyjnego w stosunku do kandydatów ubiegających się o przyjęcie do służby w Policji (Dz. U. poz. 432 ze zm.), $\$ 2$ rozporządzenia Ministra Spraw Wewnętrznych i Administracji z dnia 21 grudnia 2015 r. w sprawie postępowania kwalifikacyjnego w stosunku do kandydatów ubiegających się o przyjęcie do służby w Państwowej Straży Pożarnej (tekst jedn.: Dz. U. z 2016 r. poz. 30), $\$ 5$ ust. 3 rozporządzenia Ministra Spraw Wewnętrznych i Administracji z dnia 10 lutego 2006 r. w sprawie postępowania kwalifikacyjnego w stosunku do kandydatów ubiegających się o przyjęcie do służby w Straży Granicznej (Dz. U. Nr 23, poz. 175 ze zm.), $\$ 2$ ust. 2 rozporządzenia Ministra Sprawiedliwości z dnia 20 września 2010 r. w sprawie postępowania kwalifikacyjnego do Służby Więziennej (Dz. U. Nr 186, poz. 1247). 
datów do służby oraz akty prawne określające przebieg postępowania kwalifikacyjnego. Praktyka ta pozwala na postawienie tezy, że w sferze faktycznej zainteresowani na jednakowych zasadach mają zagwarantowane prawo do minimum informacji o naborze, który w przypadku służb specjalnych ma w pewnym sensie charakter ciągły. Właściwe w sprawie postępowania komórki gromadzą pulę danych osób ubiegających się o przyjęcie do służby. Jednakże postępowanie kwalifikacyjne prowadzi się wobec osób, które zostały poinformowane o przyjęciu podania ${ }^{14} \mathrm{i}$ które wzywa się do dostarczenia koniecznych w sprawie dokumentów. Wchodzące w grę przepisy nie rozstrzygają jednoznacznie kwestii, czy każde podanie będące w dyspozycji komórki prowadzącej postępowanie musi być wzięte pod uwagę $\mathrm{w}$ razie zaistnienia potrzeby obsadzania wolnego stanowiska. Tylko tego rodzaju obowiązek prowadzącego postępowanie uzasadniałby stwierdzenie, że w obecnym stanie prawnym uczyniono zadość obowiązkowi wynikającemu $\mathrm{z}$ art. 60 Konstytucji RP.

Należy zatem postulować działania prawodawcze, które przy uwzględnieniu specyfiki działania służb specjalnych doprowadziłyby do uregulowania formy i zakresu podawania do przestrzeni publicznej informacji niezbędnych $\mathrm{w}$ kontekście realizacji prawa zagwarantowanego $\mathrm{w}$ art. 60 Konstytucji RP.

\section{Klasyfikacja postępowań kwalifikacyjnych do służb mundurowych}

Jak słusznie zauważa Trybunał Konstytucyjny, bez stworzenia gwarancji proceduralnych zapewniających weryfikowalność decyzji zapadających w związku z naborem do służby publicznej nie można mówić o konstytucyjności tych przepisów prawa materialnego, które ustanawiają inne niż obywatelstwo i korzystanie z pełni prawa publicznych warunki dostępu do służby publicznej. W tym kontekście konieczna staje się nie tylko próba określenia modelu postępowania kwalifikacyjnego, ale przede wszystkim rozważenie problemu charakteru prawnego postępowania kwalifikacyjnego, respektowania jego toku oraz formy kończącej to postępowanie ${ }^{15}$.

W piśmiennictwie podjęto, jak do tej pory, dwie próby systematyki postępowań kwalifikacyjnych do służb mundurowych. Autor pierwszej $\mathrm{z}$ nich wyodrębnił modele normatywne, a za kryterium podziału uznał stopień szczegółowości uregulowania postępowania kwalifikacyjnego, który pozwolił na wyróżnienie dwóch modeli ${ }^{16}$ : właściwego dla kandydatów

14 Por. $\$ 3$ ust. 1 rozporządzenia Prezesa Rady Ministrów z dnia 29 listopada 2002 r. w sprawie wzoru kwestionariusza osobowego oraz szczegółowych zasad i trybu przeprowadzania postępowania kwalifikacyjnego wobec kandydatów do służby w Agencji Bezpieczeństwa Wewnętrznego, tekst jedn.: Dz. U. z 2014 r. poz. 61 ze zm.

15 Por. wyrok TK z dnia 9 czerwca 1998 r., K 28/97.

16 Wskazano trzy modele, przy czym jeden z nich, dotyczący postępowania poprzedzającego nawiązanie stosunku służbowego w Siłach Zbrojnych, pozostaje poza sferą zainteresowania niniejszego opracowania, dlatego też zostanie pominięty. 
do służby w ABW, AW, BOR, SG oraz dla kandydatów do służby w Policji oraz Państwowej Straży Pożarnej. Istotą pierwszego z nich miałaby być uregulowana procedura postępowania, natomiast drugiego - $\mathrm{w}$ zasadzie pełna dowolność organu prowadzącego postępowanie ${ }^{17}$. Mankamentem tego modelu jest $\mathrm{z}$ jednej strony przyjęte kryterium podziału, $\mathrm{z}$ drugiej zaś pominięcie $\mathrm{w}$ analizie postępowania poprzedzającego nawiązanie stosunku służbowego w Służbie Więziennej, Służbie Kontrwywiadu Wojskowego oraz Centralnym Biurze Antykorupcyjnym. Nie wydaje się bowiem zasadne wyodrębnianie modelu, który sprowadzałby się do „braku kompleksowej regulacji zagadnień związanych z rekrutacją funkcjonariuszy"18. W zaproponowanym ujęciu model ten polegałby na braku modelu.

Bardziej trafne wdaje się przyjęcie jako kryterium klasyfikacji postępowań kwalifikacyjnych umiejscowienia kompetencji do prowadzenia postępowania. Pozwoliło ono na wyodrębnienie postępowań wewnątrzzakładowych, wewnątrzzakładowo-służbowych oraz służbowych ${ }^{19}$. Pierwsze z nich sprowadza się do ograniczenia procedury kwalifikacyjnej do ram danej jednostki organizacyjnej, która ma zatrudnić przyjętego funkcjonariusza, i obejmuje kandydatów do funkcjonariuszy Służby Więziennej, Państwowej Straży Pożarnej oraz kandydatów do służby w Komendzie Głównej Policji oraz komendach wojewódzkich tej formacji. Postępowanie wewnątrzakładowo-służbowe prowadzone jest wobec osób ubiegających się o przyjęcie do służby w Straży Granicznej i oprócz etapu prowadzonego w jednostce SG, na potrzeby której prowadzi się nabór, obejmuje również etap na szczeblu centralnym, to jest przed komisją powoływaną przez Komendanta Głównego SG. Katalog typów postępowań kwalifikacyjnych dopełnia model, w którym postępowanie kwalifikacyjne prowadzi kierownik komórki kadrowej. Podobnie jest w ABW, AW, BOR, CBA, SKW oraz SWW ${ }^{20}$.

Nie kwestionując zasadniczej przydatności przedstawionej typizacji postępowań kwalifikacyjnych, trudno zgodzić się z wyodrębnieniem postępowania kwalifikacyjnego typu służbowego. Według autora tej koncepcji jest ono typowe dla osób ubiegających się o zatrudnienie w charakterze funkcjonariuszy podstawowych ${ }^{21}$ jednostek organizacyjnych Policji funkcjonujących w terytorialnym zasięgu działania komendanta wojewódzkiego.

17 J. Stelina, Strony i nawiazanie stosunków służbowych [w:] T. Kuczyński, E. Mazurczak-Jasińska, J. Stelina, System Prawa Administracyjnego, t. 11, Stosunek stużbowy, Warszawa 2011, s. 214-216.

18 Ibidem, s. 216.

19 T. Kuczyński, Administracyjnoprawne zatrudnienie niepracownicze [w:] System Prawa Pracy, t. VII, Zatrudnienie niepracownicze, K.W. Baran (red.), Warszawa 2015, s. 426.

20 Ibidem, s. 426-427.

$21 \mathrm{~W}$ przepisach przepisy ustawy o Policji nie funkcjonuje zwrot „podstawowe jednostki organizacyjne Policji”, ale wnosząc z przepisów określających strukturę organizacyjną Policji, należałoby za nie uznać komendy powiatowe (miejskie) Policji. 
Postępowanie to nie jest powadzone przez podstawowe jednostki organizacyjne Policji, które mają zatrudnić funkcjonariusza, ale przez ponadzakładowe (wojewódzkie) struktury służbowe ${ }^{22}$. Akceptacja tej propozycji prowadziłaby do trudnego do przyjęcia wniosku, iż kwalifikacja kandydatów do służby w Policji odbywa się według odmiennych modeli.

Rozważając zagadnienie modeli czy też typów postępowań kwalifikacyjnych w służbach mundurowych, warto zwrócić uwagę na niejednolite oznaczenie podmiotu prowadzącego postępowanie. I tak np. w przypadku postępowania kwalifikacyjnego związanego z naborem do Biura Ochrony Rządu, określonego w rozporządzeniu Ministra Sprawa Wewnętrznych i Administracji z dnia 18 lutego 2004 r. w sprawie szczegółowego trybu prowadzenia postępowania kwalifikacyjnego do służby przygotowawczej oraz do służby kandydackiej w Biurze Ochrony Rządu ${ }^{23}$, postępowanie to prowadzi zgodnie $\mathrm{z} \$ 2$ ust. 1 komórka organizacyjna BOR właściwa $\mathrm{w}$ sprawach osobowych (podobnie przewidziano $\mathrm{w}$ przepisach regulujących postępowanie kwalifikacyjne wobec kandydatów do służby w SKW i SWW). Postępowanie kwalifikacyjne do służby w ABW oraz AW prowadzi kierownik jednostki organizacyjnej w sprawach kadrowych. Jeszcze inaczej kwestia ta została uregulowana $\mathrm{w}$ odniesieniu do postępowania kwalifikacyjnego do służby w CBA. Jak wynika z przepisów rozporządzenia Prezesa Rady Ministrów z dnia 20 lipca 2006 r. w sprawie wzoru kwestionariusza osobowego oraz szczegółowego trybu przeprowadzania postępowania kwalifikacyjnego wobec kandydatów do służy w Centralnym Biurze Antykorupcyjnym $^{24}$, niektórych czynności w toku postępowania dokonują funkcjonariusze jednostki organizacyjnej CBA właściwej w sprawach kadrowych, ale zakończenie postępowania wymaga powołania przez Szefa CBA specjalnej komisji, która dokonuje oceny predyspozycji kandydata do służby w CBA. Równocześnie, jak stanowi $₫ 3$ ust. 2 rozporządzenia, jednostka organizacyjna właściwa w sprawach kadrowych może odmówić poddania kandydata postępowaniu kwalifikacyjnemu albo przerwać je w każdym czasie. Rozwiązanie to daje asumpt do stwierdzenia, że podobnie jak $\mathrm{w}$ formacjach mundurowych wskazanych $\mathrm{w}$ tej grupie również w CBA postępowanie kwalifikacyjne prowadzi komórka kadrowa, a od pewnego etapu komisja powoływana przez Szefa CBA.

Z kolei zgodnie z $\$ 7$ rozporządzenia Ministra Spraw Wewnętrznych i Administracji w sprawie postępowania kwalifikacyjnego w stosunku do kandydatów ubiegających się o przyjęcie do służby w Policji postępowanie to prowadzi Komendant Główny Policji lub komendant wojewódzki (stołeczny) Policji.

22 T. Kuczyński, Administracyjnoprawne..., s. 427.

23 Dz. U. Nr 37, poz. 338.

24 Dz. U. Nr 133, poz. 936. 
W Państwowej Straży Pożarnej postępowanie to prowadzi, jak stanowi art. 28 ust. 4 ustawy z dnia 24 sierpnia 1991 r. o Państwowej Straży Pożarnej ${ }^{25}$, kierownik jednostki organizacyjnej Państwowej Straży Pożarnej ${ }^{26}$.

Postępowanie kwalifikacyjne do Służby Więziennej, zgodnie z $\$ 1$ rozporządzenia Ministra Sprawiedliwości z dnia 20 września 2010 r. w sprawie postępowania kwalifikacyjnego do Służby Więziennej, przeprowadza kierownik jednostki organizacyjnej Służby Więziennej ${ }^{27}$, o przyjęcie do której ubiega się kandydat do Służby Więziennej przy pomocy funkcjonariusza Służby Więziennej lub pracownika realizującego zadania kadrowe w tej jednostce.

Podniesiona wyżej kwestia sposobu określenia podmiotu prowadzącego postępowanie ma, jak się wydaje, znaczenie nie tylko terminologiczne. Wskazanie, że postępowanie kwalifikacyjne prowadzi określona jednostka organizacyjna danej formacji czy też kierownik takiej jednostki, rozstrzyga kwestię techniczno-organizacyjną. Przy założeniu, że postępowanie kwalifikacyjne jest postępowaniem $\mathrm{z}$ zakresu administracji publicznej ${ }^{28}$, dokonywane wobec kandydata czynności, takie jak niedopuszczenie go do udziału w postępowaniu, przerwanie go a wreszcie ocena, należy uznać za inne czynności z zakresu administracji publicznej w rozumieniu art. $3 \$ 2$ pkt 4 ustawy z dnia 30 sierpnia 2002 r. - Prawo o postępowaniu przed sądami administracyjnymi ${ }^{29}$. Stroną $\mathrm{w}$ ewentualnym postępowania sądowoadministracyjnym na skutek skargi kandydata będzie nie określona komórka organizacyjna formacji mundurowej czy jej pracownik, ale właściwy organ danej formacji ${ }^{30}$.

Mając na uwadze dotychczasowe wywody, można zaproponować jeszcze jeden sposób klasyfikowania postępowań kwalifikacyjnych do służb mundurowych, przy zastosowaniu kryterium podziału, którym jest formalny akt ich zakończenia. Pomijając pewne różnice terminologiczne, ocena kandydata może być zestawiona w dokumencie z ocenami innych osób, wobec których toczyło się postępowanie, albo przedstawiona jako samodzielna,

25 Tekst jedn.: Dz. U. z 2017 r. poz. 1204.

26 Zgodnie z art. 8 ust. 1 ustawy o Państwowej Straży Pożarnej są nimi: Komenda Główna, komenda wojewódzka, komenda powiatowa (miejska), Szkoła Główna Służby Pożarniczej oraz pozostałe szkoły, instytuty badawcze oraz Centralne Muzeum Pożarnictwa.

27 Jak stanowi art. 8 ust. 1 ustawy z dnia 9 kwietnia 2010 r. o Służbie Więziennej (tekst jedn.: Dz. U. z 2017 r. poz. 631 ze zm.), jednostkami organizacyjnymi Służby Więziennej są: Centralny Zarząd Służby Więziennej, okręgowe inspektoraty Służby Więziennej, zakłady karne i areszty śledcze, Centralny Ośrodek Szkolenia Służby Więziennej oraz ośrodki szkolenia Służby Więziennej i ośrodki doskonalenia kadr Służby Więziennej.

28 Zob. uwagi poniżej.

29 Tekst jedn.: Dz. U. z 2016 r. poz. 718 ze zm.; dalej p.p.s.a.

30 To, jaki konkretnie będzie to organ, zależy od sposobu unormowania kwestii działania danej formacji w sprawach osobowych. 
niezestawiana formalnie $\mathrm{z}$ oceną innych kandydatów. W pierwszym przypadku sporządzana jest lista kandydatów w kolejności ustalonej w oparciu o wyniki uzyskane $\mathrm{w}$ trakcie postępowania. Takie rozwiązanie przewidują przepisy regulujące postępowanie kwalifikacyjne w PSP, SW i Policji. Podobnie sytuacja wygląda w SG, przy czym w tym wypadku sporządza się listy zbiorcze, odrębnie dla każdej z jednostek organizacyjnych, do których przeprowadzany jest nabór. Nie ma obowiązku sporządzania takiej listy w przypadku prowadzenia postępowania kwalifikacyjnego dla kandydatów do służby w ABW, AW, BOR, CBA, SKW i SWW.

Zaletą zaproponowanej typizacji postępowania jest wyeksponowanie konkursowego w istocie rzeczy charakteru postępowań w tych formacjach, w których postępowanie kończy się sporządzeniem listy kandydatów. Stosunki służbowe nawiązuje się $\mathrm{w}$ nich stosownie do zapotrzebowania etatowego, w kolejności wynikającej z miejsca na liście. W przypadku pozostałych formacji właściwy $\mathrm{w}$ sprawie nawiązania stosunku służbowego przełożony będzie miał większą swobodę, a jego wybór w tym zakresie będzie ograniczony jedynie do kandydatów, którzy uzyskali pozytywną ocenę predyspozycji do służby.

\section{Charakter prawny postępowania kwalifikacyjnego}

Kolejnym zagadnieniem związanym z postępowaniem kwalifikacyjnym jest jego charakter prawny. Jak już wyżej zauważono, postępowanie kwalifikacyjne służy osiągnięciu pewnego celu: ustaleniu, czy kandydat spełnia określone prawem materialnym warunki przyjęcia do służby. Konieczność jego prowadzenia stanowi oczywistą konsekwencję uznania przez prawodawcę, że służbę, rozumianą jako przedmiot regulacji prawnej, mogą pełnić osoby o odpowiednich kwalifikacjach, predyspozycjach i zdolnościach. Wyrazem tego przekonania jest ustanowienie rygorów selekcyjnych. Tam, gdzie w sferze publicznej nawiązywany jest stosunek zatrudnienia, do którego dostęp ograniczają pewne wymogi kwalifikacyjne stawiane kandydatom do zatrudnienia, konieczne jest ustanowienie odpowiedniej procedury, w trakcie której ustala się, czy spełniają je chętni do zatrudnienia. Poczynione uwagi mają na celu wykazanie istotowego podobieństwa wszelkich określonych prawem procedur selekcyjnych związanych z zatrudnianiem, co jak się wydaje, uzasadnia korzystanie z dorobku doktryny i orzecznictwa powstałego na tle wspomnianych postępowań. Szczególne znaczenie w tym zakresie mają postępowania poprzedzające nawiązanie stosunków pracy w samorządzie terytorialnym oraz służbie publicznej. Poczynione spostrzeżenie pozwala na postawienie tezy, że postępowania $\mathrm{w}$ sprawie przyjęcia do służby $w$ formacjach mundurowych mają, podobnie jak postępowania zmierzające do wyłonienia kandydata na stanowisko urzędnicze, charakter postępowań z zakresu administracji publicznej. Działania podejmowane 
w ich toku są prowadzone przez właściwe tym zakresie podmioty, które podejmują swoje czynności w trybie i w sposób określony przepisami prawa administracyjnego. Prowadzi to do oczywistego wniosku, że końcowy efekt działania podmiotów prowadzących postępowanie kwalifikacyjne jest, jak to ujmuje nauka prawa administracyjnego, prawną formą działania administracji. Zasadne zatem staje się postawienie pytania, którą z nich jest akt kończący postępowanie kwalifikacyjne, a w szczególności, czy może być on uznany za indywidualny akt administracyjny.

Jak już powiedziano, zasadniczo postępowanie kończy się sporządzeniem oceny predyspozycji bądź zbiorczej listy kandydatów. Jednakże przepisy regulujące te postępowania przewidują możliwość, a niekiedy obowiązek, odstąpienia od dalszego jego prowadzenia. Rozwiązanie to co do zasady jest $\mathrm{w}$ pełni uzasadnione. Niespełnienie nawet jednego z rygorów kwalifikacyjnych przewidzianych w pragmatykach służbowych czyni postępowanie bezprzedmiotowym i implikuje negatywną ocenę końcową, a zatem uniemożliwia nawiązanie stosunku służbowego. Dla zakończenia postępowania $\mathrm{w}$ odniesieniu do konkretnego kandydata nie zawsze konieczne jest przeprowadzenie całej skomplikowanej procedury określonej wchodzącymi w grę przepisami. Postępowania kwalifikacyjne, angażując zasoby kadrowe służb mundurowych, generują określone koszty pokrywane ze środków publicznych. Względy racjonalności i oszczędności należycie uzasadniają zatem odstąpienie od prowadzenia postępowania $\mathrm{w}$ razie niespełniania przez kandydata jasno określonego w przepisach warunku. Nie oznacza to jednak, że podmiot prowadzący postępowanie wydaje rozstrzygnięcie tego typu na zasadzie dowolności. Należy bowiem zauważyć, że obowiązujące $\mathrm{w}$ tym zakresie przepisy pozwalają na przerwanie postępowania bez podawania kandydatowi przyczyny tego rozstrzygnięcia. Takie rozwiązanie przyjęto $\mathrm{w}$ rozporządzeniach regulujących postępowanie kwalifikacyjne wobec kandydatów ubiegających się o przyjęcie do służby w ABW, AW, CBA, SKW oraz SWW. Decyzja podmiotu prowadzącego postępowanie o jego przerwaniu nie ma przy tym charakteru uznaniowego. Warunkiem sine qua non jej podjęcia jest niespełnienie przez kandydata nawet jednego $\mathrm{z}$ wymogów wynikających $\mathrm{z}$ danej pragmatyki służbowej. Zasygnalizowany problem był przedmiotem rozstrzygnięcia NSA w Warszawie, który w wyroku z dnia 4 lipca 2014 r., I OSK 3044/12 $2^{31}$ stwierdził obowiązek podania kandydatowi, wobec którego przerwano postępowanie kwalifikacyjne, przyczyn tego rozstrzygnięcia. Sąd uznał, że akt ten mieści się w kognicji sądów administracyjnych, będąc przykładem aktów i czynności z zakresu administracji publicznej w ujęciu art. $3 \$ 2$ pkt 4 p.p.s.a. Pogląd ten, wyrażony jeszcze przed zmianą przywołanego przepisu Prawa o postępowaniu przed sądami administracyjnymi, zachowuje swoją aktualność w obecnym stanie prawnym. Przerwanie postępowania przez

31 LEX nr 1480278. 
podmiot prowadzący postępowanie kwalifikacyjne nie jest decyzją administracyjną ani postanowieniem w rozumieniu przepisów o postępowaniu administracyjnym, postępowaniem egzekucyjnym $\mathrm{w}$ administracji ani postanowieniem o postępowaniu zabezpieczającym w administracji. Ma przy tym charakter zewnętrzny, gdyż jest skierowane do podmiotu usytuowanego poza strukturą organizacyjną organu administracji, oraz cechuje się „podwójną konkretnością" ${ }^{32}$. Jest skierowane do indywidualnego adresata, znajdującego się w określonej (konkretnej) sytuacji wyznaczonej przez przepisy pragmatyk służbowych oraz przepisy rozporządzeń normujących postępowanie kwalifikacyjne. Nie ulega przy tym wątpliwości, że każde z postępowań kwalifikacyjnych dotyczy uprawnień wynikających z przepisów prawa, jako że pozytywny wynik postępowania kwalifikacyjnego bezpośrednio dotyka konstytucyjnego prawa obywatelskiego - dostępu do służby publicznej. Wynik postępowania kwalifikacyjnego, zarówno pozytywny, jak i negatywny, rozumiany jako odstąpienie od jego prowadzenia, w sposób prawnie wiążący wpływa na sytuację prawną kandydata, wprowadzając prawnie wiążący element „nowości normatywnej”33.

Wreszcie na rzecz tezy o tym, że oceny kwalifikacyjne, indywidualne i zbiorowe stanowią inne akty i czynności z zakresu administracji publicznej w ujęciu art. $3 \$ 2$ pkt 4 p.p.s.a., przemawia aspekt formalny. W postępowaniach tych nie stosuje się $\mathrm{w}$ zakresie nieunormowanym przepisami stosownych rozporządzeń przepisów ustawy z dnia 14 czerwca 1960 r. Kodeks postępowania administracyjnego ${ }^{34}$, co potwierdził Wojewódzki Sąd Administracyjny w Krakowie w postanowieniu z dnia 10 marca 2015 r., III SAB/Kr 12/15 35 Sąd uznał, że postępowanie kwalifikacyjne do służby w Policji nie jest postępowaniem administracyjnym, do którego mają zastosowanie przepisy Kodeksu postępowania administracyjnego, lecz procedurą wewnętrzną.

Nie ulega zatem wątpliwości, że podmiot prowadzący postępowanie kwalifikacyjne decydując o jego przerwaniu z powodu niespełnienia przez kandydata wymogów wynikających z konkretnej pragmatyki służbowej, powinien podać kandydatowi przyczynę swojego rozstrzygnięcia. Tymczasem w przepisach rozporządzeń regulujących takie postępowania w służbach specjalnych znajdują się przepisy stanowiące o możliwości odmowy poddania kandydata postępowaniu lub odstąpienia do niego w każdym czasie.

32 Por. M. Bogusz, Pojęcie aktów i czynności z zakresu administracji publicznej dotyczacych przyznania, stwierdzenia albo uznania uprawnienia lub obowiazku wynikających $z$ przepisu prawa $w$ rozumieniu art. 16 ust. 1 pkt 4 ustawy o NSA, „Samorząd Terytorialny" 2000, nr 1-2, s. 181.

33 Ibidem, s. 183.

34 Tekst jedn.: Dz. U. z 2016 r. poz. 23 ze zm.

35 LEX nr 1660224. 
W świetle poczynionych wyżej uwag oczywiste staje się stwierdzenie, że uprawnienie pozwalające na przerwanie postępowania kwalifikacyjnego bez podawania przyczyny rodzi wątpliwości natury konstytucyjnej, a konkretnie zarzut niezgodności z wyrażoną w art. 60 Konstytucji RP zasadą dostępu do służby na jednakowych zasadach. W myśl art. 31 ust. 3 Konstytucji RP ograniczenia w korzystaniu z konstytucyjnych wolności i praw mogą być ustanawiane tylko w ustawie.

Problem związany możliwością przerwania postępowania kwalifikacyjnego bez podania przyczyn dostrzegł Rzecznik Praw Obywatelskich, który już w 2010 r. wystąpił do Trybunał Konstytucyjnego o stwierdzenie niezgodności art. 25 ust. 3 ustawy o Policji oraz $\$ 20$ ust. 2 rozporządzenia Ministra Spraw Wewnętrznych i Administracji z dnia 30 sierpnia 2007 r. w sprawie postępowania kwalifikacyjnego w stosunku do osób ubiegających się o przyjęcie do służby w Policji ${ }^{36}$. W wystąpieniu swym RPO słusznie jednak zauważyl, że pierwotnym problemem występującym w owym czasie $\mathrm{w}$ związku $\mathrm{z}$ uregulowaniem postępowania kwalifikacyjnego do służby w Policji był kształt ustawowego upoważnienia w drodze rozporządzenia zasad i trybu postępowania kwalifikacyjnego. Ostatecznie wniosek RPO nie doczekał się rozpatrzenia, jako że zakwestionowane przez niego regulacje utraciły moc obowiązującą, wskutek czego TK umorzył postępowanie $^{37}$. Argumenty Rzecznika Praw Obywatelskich o wadliwym sformułowaniu upoważnienia do uregulowania $\mathrm{w}$ drodze rozporządzeń postępowań kwalifikacyjnych do służb mundurowych zachowują swą wartość wobec adekwatnych przepisów pragmatyk służbowych służb specjalnych (ABW, AW, CBA, SKW, SWW), Biura Ochrony Rządu oraz Straży Granicznej.

\section{Wnioski}

1. Postępowania kwalifikacyjne wobec kandydatów do służby w formacjach mundurowych ściśle wiążą się z zagwarantowanym konstytucyjnie prawem dostępu do służby publicznej. Warunkiem koniecznym do urzeczywistnienia tego prawa jest podawanie do publicznej wiadomości informacji o prowadzonym naborze na wolne stanowiska. Zważywszy na argument racjonalnego ustawodawcy, zasadny wydaje się postulat wprowadzenia spójnej regulacji w zakresie obowiązku informowania o prowadzonym naborze. Postulat ten nie wyklucza zasadności specyficznego unormowania zagadnienia $\mathrm{w}$ przypadku prowadzenia naboru do służb specjalnych. Nie można przy tym a priori wykluczyć w odnie-

36 Dz. U. Nr 170, poz. 1202. Obecnie w tym zakresie obowiązuje rozporządzenie z Ministra Spraw Wewnętrznych i Administracji z dnia 18 kwietnia 2012 r. w sprawie postępowania kwalifikacyjnego w stosunku do kandydatów ubiegających się o przyjęcie do służby w Policji.

37 Postanowienie TK z dnia 22 listopada 2011 r., K 10/10, „Orzecznictwo Trybunału Konstytucyjnego", seria A 2011, nr 9, poz. 12. 
sieniu do niektórych służb ograniczenia zakresu prawa zagwarantowanego $\mathrm{w}$ art. 60 Konstytucji RP. Wymagałoby to jednak spełnienia warunków przewidzianych w art. 31 ust. 3 Konstytucji RP.

2. Postępowania kwalifikacyjne wobec kandydatów do służby w formacjach mundurowych są postępowaniami z zakresu administracji publicznej. Czynności dokonywane wobec kandydata w toku postępowania $\mathrm{w}$ postaci niedopuszczenia go do udziału w postępowaniu, przerwania postępowania wobec określonego kandydata czy ostatecznej oceny są „innymi czynnościami z zakresu administracji publicznej” $\mathrm{w}$ rozumieniu art. $3 \$ 2$ pkt 4 p.p.s.a. i wymagają podania przyczyny takiego rozstrzygnięcia.

3. Na czynności podmiotu prowadzącego postępowanie takie jak niedopuszczenie kandydata do udziału w postępowaniu kwalifikacyjnym, przerwanie postępowania wobec określonego kandydata oraz ostateczna ocena służy skarga do sądu administracyjnego.

4. De lege ferenda należy postulować takie sformułowanie delegacji ustawowych do wydania aktów wykonawczych regulujących postępowania kwalifikacyjne, by czyniło ono zadość wymogom określonym dla tego rodzaju przepisów w art. 92 ust. 1 Konstytucji RP.

\section{Bibliografia}

Bogusz M., Pojęcie aktów i czynności z zakresu administracji publicznej dotyczących przyznania, stwierdzenia albo uznania uprawnienia lub obowiązku wynikajacych $z$ przepisu prawa $w$ rozumieniu art. 16 ust. 1 pkt 4 ustawy o NSA, „Samorząd Terytorialny" 2000, nr 1-2.

Kuczyński J., Administracyjnoprawne zatrudnienie niepracownicze [w:] System Prawa Pracy, t. VII, Zatrudnienie niepracownicze, K.W. Baran (red.), Warszawa 2015.

Stelina J., Strony i nawiązanie stosunków służbowych [w:] T. Kuczyński, E. Mazurczak-Jasińska, J. Stelina, System Prawa Administracyjnego, t. 11, Stosunek stuzbowy, Warszawa 2011.

Streszczenie

$\mathrm{W}$ artykule podjęto zagadnienie regulacji postępowań kwalifikacyjnych poprzedzających nawiązanie stosunków służbowych z funkcjonariuszami tzw. formacji mundurowych. Prawodawca nie zdecydował się na wprowadzenie jednolitego dla wszystkich formacji mundurowych modelu postępowania kwalifikacyjnego, co jest uzasadnione specyfiką zadań realizowanych przez poszczególne formacje. Niezależnie jednak od uzasadnionych różnic między postępowaniami kwalifikacyjnymi w różnych formacjach mundurowych można wskazać zasadnicze podobieństwo, które polega na tym, że wszystkie wiążą się z prawem dostępu do służby publicznej, ustanowionym w art. 60 Konstytucji RP. Podjęcie rozważań w tym zakresie uzasadnia przede wszystkim ranga problemu, ale i marginalizowanie regulacji postępowań kwalifikacyjnych przez przedstawicieli nauki prawa. Celem opracowania było rozstrzygnięcie wątpliwości co 
do charakteru prawnego postępowań kwalifikacyjnych i czynności podejmowanych $\mathrm{w}$ toku tych postępowań oraz dokonanie oceny przepisów regulujących postępowania kwalifikacyjne w aspekcie prawa dostępu do służby publicznej i formalnych gwarancji tego prawa. W wyniku analizy odpowiednich przepisów stwierdzono, że postępowania kwalifikacyjne wobec kandydatów do służby w formacjach mundurowych są postępowaniami z zakresu administracji publicznej, czynności podejmowane przez podmiot prowadzący dane postępowanie są zaś „innymi czynnościami z zakresu administracji publicznej" w rozumieniu art. $3 \$ 2$ pkt 4 p.p.s.a. Na czynności podmiotu prowadzącego postępowanie, takie jak niedopuszczenie kandydata do udziału w postępowaniu kwalifikacyjnym, przerwanie postępowania wobec określonego kandydata oraz ostateczna ocena, służy zatem skarga do sądu administracyjnego. Dostrzeżono również potrzebę wprowadzenia przepisów porządkujących kwestię informowania o naborze na wolne stanowiska służbowe w formacjach mundurowych jako podstawowego warunku realizacji prawa dostępu do służby publicznej.

Słowa kluczowe: postępowanie kwalifikacyjne, służba publiczna, funkcjonariusz

\section{The Recruitment Procedure Applied to Candidates for Uniformed Services}

Abstract

The article deals with regulations concerning the recruitment procedure which precedes employment of officers of uniformed services. The legislator did not decide to introduce a uniform model of recruitment procedure for all uniformed services, which is justified given specific tasks performed by particular services. Regardless of the justified differences between recruitment procedure concerning various uniformed services, a substantial similarity may be shown, namely that all of them are associated with the right of access to the public service, laid down in Article 60 of the Polish Constitution of 2 April 1997. The rationale for such considerations is justified by the significance of the problem, but also by the fact that regulations governing the recruitment procedure are marginalised by law scientists. The purpose of the study is to resolve the doubts concerning the legal nature of the recruitment procedure and the activities taken in its course as well as to assess the provisions governing the recruitment procedure in the context of the right of access to the public service and the formal guarantees of that right. As a result of the analysis of the relevant provisions, it has been found that the recruitment procedure for candidates for uniformed services is public administration proceedings. Activities undertaken by the entity conducting a particular procedure are "other public administration activities" within the meaning of Article 3(2)(4) of the Act on proceedings in administrative courts of 30 August 2002. The activities of the entity conducting the proceedings, such as exclusion of the candidate to take part in the recruitment process, staying of proceedings against a particular candidate and the final assessment may therefore be the object of a complaint lodged with the administrative court. Also recognised is the need to introduce legal provisions systematising the issue of notification of recruitment for vacant positions in uniformed services as the basic condition for the implementation of the right of access to the public service.

Keywords: recruitment procedure, public service, public official 